\title{
Exporting Transparency Through Mergers
}

\author{
Mohammad Refakar ${ }^{1}$, Jean-Pierre Gueyie ${ }^{2}$ \& Jean-Yves Filbien ${ }^{3}$ \\ ${ }^{1}$ École de Gestion, Université of Sherbrooke, Sherbrooke, Canada \\ ${ }^{2}$ École des Sciences de la Gestion, Université du Québec à Montréal, Montréal, Canada \\ ${ }^{3}$ Université of Lille, Lille, France \\ Correspondence: Mohammad Refakar, École de Gestion, Université of Sherbrooke, Sherbrooke, Qc., J1K 2R1, \\ Canada. Tel: 819-821-8000, ext. 62362. E-mail: Mohammad.Refakar@USherbrooke.ca
}

Received: May 13, 2019

doi:10.5539/ijef.v11n7p110
Accepted: June 4, 2019

Online Published: June 14, 2019

\begin{abstract}
Openness to trades can intensify competition in a country and confine the possibilities of rent creation and extraction. Mergers and acquisitions introduce competition in the markets and bring not only capital and technologies, but also new norms and policies. This study examines to what extend openness to trades and competition intensification through M\&A could affect the level of corruption in a country. Our study focuses on the effect of M\&A activity (as a proxy for openness to trades) on corruption levels. Using a large panel of 50 countries over a 16-year period, we find evidence that openness to trades helps countries reduce their level of corruption.
\end{abstract}

Keywords: corruption, mergers and acquisitions, openness to trades

\section{Introduction}

"There is no compromise when it comes to corruption. You have to fight it."

- A. K. Antony, former defence minister of India and member of the parliament (as cited in Ullekh, 2012).

There have been many studies on the effects of foreign direct investment (FDI) inflows on host country corruption, but no study has investigated the effects of mergers and acquisitions (M\&A) on the host country's level of corruption. This is somewhat surprising since M\&A are the most important component of FDI, the share of M\&A in FDI has been increasing in recent years, and M\&A have become a primary mode of internationalization (UNCTAD, 2000). At the same time, policy makers view corruption as a major hindrance to economic growth and development. As a result, the fight against corruption has received considerable attention and international organizations such as the UN, the IMF and the OECD have taken a special interest in anti-corruption movements. In fact, corruption is arguably the most serious problem in developing countries (e.g., Bardhan, 1997) and it is also a challenge for many developed countries (Kaufmann, 2004). Corruption can only be remedied if its causes and determinants are identified. This study find evidence that M\&A activity is one of these determinants and decrease corruption.

Literature on corruption identifies three prerequisites for corruption: the discretionary power of public officials, the association of this power with economic rents, and the probability of these officials getting caught and being penalized (Jain, 2001). Lawyers often argue that the legal systems should be reformed so that the punishment for public officials who engage in corruption would be increased. Businessmen argue that bureaucrats should receive a higher salary so that their motivation to fraud would decrease. However, the existence of economic rents fosters corruption (Ades \& Di Tella, 1997) and the possibility of corrupt transactions will decrease if bureaucrats have less opportunity to extract or create economic rents (Braguinsky, 1996). As one solution, Ades and Di Tella (1997) suggest an economist's approach to control corruption by increasing the competition in the markets. Competition can affect corruption in two ways: first, competition lowers the chances of the exploitation of discretionary power by officials. Reduced official discretion will reduce the potential for corruption (Rose-Ackerman, 1997). Second, Rose-Ackerman (1975) suggested that a way to reduce corruption is to introduce competition at the level of the official receiving bribes: when a bureaucrat dispenses a scarce benefit, the existence of competing officials to reapply in case of being asked a bribe will bid down the equilibrium amount of corruption. Competition can decrease the possibility of rent creation and extraction thus hindering 
corruption.

Focusing on M\&A activity as the proxy for openness and competition is reasonable for several reasons. First, cross-border deals occur frequently and the M\&A market is voluminous. Second, foreign investors bring new culture, norms and technologies which are spilled over to domestic firms. M\&A introduce more competition in host countries because they are by far the main type of investment in a foreign country and M\&A are more effective in introducing change to the target firms through ownership. Third, domestic M\&A facilitate the spread of these new norms and culture. The presence of foreign investors and multinationals along with domestic acquisitions therefore intensify competition. Moreover, competition restricts the profits of engaging in a corrupt transaction and discourages public officials from initiating corrupt behaviour.

In this study we investigate the effects of M\&A on host country corruption. To the best of our knowledge, this is the first study that empirically analyzes the relationship between the intensity of M\&A and local corruption. This study brings new insights into our understanding of corruption. We find evidence that both cross-border M\&A volume and M\&A number could decrease corruption in the target company. Moreover, the domestic M\&A could lower corruption levels of the country.

\subsection{Investment and Corruption}

Corruption is usually understood as the "misuse of public power for private gain", where private gain may occur either to the individual official or to the group to which they belong. The issue of corruption has attracted the interest of many political scientists and economists in recent years. Early studies mainly focused on the consequences of corruption and showed that corruption deters economic development and growth. These bodies of literature have been pioneered by Mauro (1995), which reports a significant negative relationship between corruption and investment that extends to growth. Several consequent studies confirm and broaden Mauro's (1995) results and extend to other macroeconomic variables such as foreign direct investment. They find that corruption has an adverse effect on foreign investment and capital inflows because it renders a country unattractive to foreign investors (Wei, 2000a; Lambsdorff \& Cornelius, 2000; Habib \& Zurawicki, 2001; 2002; Lambsdorff, 2003).

Later studies investigate the causes of corruption to understand why some countries exhibit higher levels of corruption than others. They find that closed markets with imperfect competition are an important source of rents. In these markets, the possibility of corrupt transactions increases when the discretionary power of the relevant bureaucrats or public officials allows extraction or creation of economic rents (Tanzi, 1998; Rose-Ackerman, 1999; Jain, 2001). Lack of competition serves as a major cause of corruption and has attracted the interest of many scholars. There studies focus on the extent to which corruption can be explained by a low level of competition among private firms. Competition is assumed to lower the prices and therefore lower the profit margin for firms, thus firms have less money to offer as a bribe. In addition, increased competition results in a more efficient allocation of resources and dissipation of rents. Lambsdorff (2005) contends that in competitive environments, public servants and politicians have less to sell in exchange for bribes, and as a result, they are less motivated to start a corrupt career. This body of literature uses different indicators of competition. Lambsdorff (1999) argues that corruption is negatively correlated with different indicators of economic freedom. This result is largely supported by Goldsmith (1999) and Paldam (2002) for a sample of more than 60 countries. Ades and Di Tella (1995, 1997 and 1999) find a negative correlation between competition and corruption and argue that corruption is higher when bureaucrats have the potential to extract larger economic rents. They argue that openness to international trade will reduce the monopolistic power of domestic producers and strengthen market competition, which in turn narrows the rents available for bureaucrats to extract. "A natural approach to corruption control is to appeal to the concept of competition as it is argued that bribes are harder to sustain where perfect competition prevails" (Ades \& Di Tella, 1999). They use country's openness, defined as the ratio of imports to GDP, as an alternative indicator of competition and find that openness, is negatively associated with corruption. Sung and Chu (2003), Sandholtz and Koetzle (2000), Sandholtz and Gray (2003), and Gerring and Thacker (2005) also report that economic competition as measured by the degree of a country's openness reduces corruption. Wei (2000b) applies a measure of "natural openness", which refers to the extent of openness in a country determined by its population and its remoteness from world trading centres. Using this alternative indicator of competition, he finds that natural openness is indeed a determinant of corruption, pointing out the helpful role of competition in decreasing corruption. Sachs and Warner (1995) assessed the number of years it has been open to trade as another possible measure of the extent of competition in a country. Treisman (2000) and Leite and Weidmann (1999) provide evidence that this variable negatively and significantly impacts on the level of corruption. 
Recently researchers focused on the level of foreign direct investment (FDI) as a measure of the extent of competition and openness of a country. Larrain and Tavares (2004) use the ratio of FDI to GDP as an indicator of openness to trade and competition, and empirically find that higher exposure to FDI tends to be related to lower corruption levels. Pinto and Zhu (2016) also use FDI as a measure of competition and find that foreign investment may generate greater competition in the marketplace. When foreign investors compete with domestic firms, economic rents are driven away, and thereby the expected benefits of engaging in corruption is decreased.

In this paper, we use M\&A intensity as an indicator of competition in the country. The volume of cross-national mergers and acquisitions has been growing worldwide. In the last decades, M\&A have become the most important component of capital inflows and foreign investment. While the degree of market diversification and competition reduces opportunities for rent creation, which in turn leads to less corruption, cross-national M\&A activity intensifies competition and fosters openness to trade in a country, and as a result, decrease corruption. As put forward by Rose-Ackerman (1975), corruption may be less frequent if it has long-term negative consequences for the firms and individuals involved, as is the case with M\&A activity. Both cross-national and domestic M\&A activity can open the economy to international trade and intensify the degree of competition within a country. Thus, total M\&A activity can be a good proxy for competition in a host country.

Cross-national economic ties can limit corruption by increasing its cost. Corrupt practices can perpetuate themselves more easily in closed economies, but in open markets corrupt officials would feel the pinch of international openness. Because bribe-paying companies suffer under international competition, they would have less money to offer, and bureaucrats would find that their corruption-related income declines. Greater exposure to international trades thus penalizes corruption. On the other hand, open societies not only import goods and capital from the rest of the world but also ideas, policies and norms. International integration has its domestic consequences. Openness to international transactions can introduce policy shifts and reform the domestic economies and politics of countries. The effects of international interactions are very substantial and can affect norms and practices that are usually determined by local social and cultural factors. Foreign investment not only brings capital, but also new technologies, marketing techniques, and management skills. The knowledge spillover through FDI has been extensively studied in the literature (Javorcik, 2004; Görg \& Greenaway, 2004; Haskel et al., 2007; etc.). However, the spillover effect is much stronger for M\&A because in international law, a full takeover leads to a change in the nationality of the target firm such that the acquirer's regulations will apply to the combined company, in effect replacing the target regulations, norms and policies (Bris \& Cabolis, 2008). If the acquirer come from a more transparent country, better regulations and policies will be transferred to the target (Martynova \& Renneboog, 2008), however an acquirer from a less transparent country would learn the skills, policies and norms from the target (Chen et al., 2012). Although corruption in a country has powerful domestic determinants, it is significantly affected by the level of international integration and openness which brings back home new norms, regulations, skills and norms. Sandholtz and Gray (2003) investigate such a relationship and find that being tied to international networks of exchange, communication and organization decreases the level of corruption. Knowledge spillovers thus are another channel through which M\&A can decrease the level of corruption in a country.

Closed economies are associated with higher possibilities of rent creation and extraction. In these environments, the introduction of competition and openness to cross-border trades can be a basic remedy for corruption. M\&A activity can open the gates of the economy and increase competition. It can also bring along ideas, norms and policies. In this paper, we assess M\&A activity for each country through six separate measures. To gauge the intensity of M\&A the literature uses the number of deals in a country and the dollar value of those deals. We use cross-border number per year, cross-border value per year, domestic number per year, domestic value per year, total number per year and total value per year. We hypothesize that a higher amount of M\&A (measured by the number per year or value per year) will decrease corruption.

\section{The Model}

To measure the effects of country-specific institutional, cultural, and political variables that affect the level of corruption over time, panel data is a rational approach. Other studies that investigate the causes of corruption neglected the effect of time and used a simple OLS regression model. The dependent variable in the panel regression equation is the Transparency International measure of corruption and the independent variables are M\&A activity measures plus the control variables. The panel model, which is used in the empirical analysis to test the hypotheses, is expressed as follows:

$$
C_{i, t}=\alpha_{0}+\beta M_{i, t-1}+\gamma^{\prime} X_{i, t}+\lambda_{t}+\theta_{i}+\varepsilon_{i, t}
$$

Where $\mathrm{C}_{\mathrm{i}, \mathrm{t}}$ is the level of corruption measured by CPI; $\mathrm{M}_{\mathrm{i}, \mathrm{t}-1}$ is the lagged M\&A activity measures in country $\mathrm{i}$ at 
time $t ; X_{i, t}$ is the vector of control variables: former colony, per capita GDP (lagged), ethnolinguistic fractionalization, oil exporter, government expenditure, population, political rights, French legal origins, and primary religion; $\beta$ and $y$ are the parameters to estimate; $\alpha_{0}$ is the portion of intercept that is common to all years and countries; $\lambda_{t}$ denotes year-specific effect common to all countries; $\theta_{\mathrm{i}}$ is the source-country fixed effects; $\varepsilon_{i, t}$ is normal error terms with mean zero and variance $\sigma_{\varepsilon}^{2}$; i stands for the country $(i=1, \ldots, N)$; and $t$ stands for the year $(t=1, \ldots, T)$. The prediction of $\beta$ is also specific to the openness hypothesis; therefore, we hypothesize a positive relationship between corruption perceptions index and M\&A (higher corruption index in associated with less corruption).

\subsection{Control Variables}

The abundant empirical literature on the determinants of corruption identifies a series of alternative conditions which will affect the analysis and choice of controls. Among the conditions found to affect corruption are:

\subsubsection{Legal Systems}

The most obvious cost of corruption is the risk of getting caught and punished (Treisman, 2000). The probability of getting caught and sanctioned depends in part on the country's legal system. The civil law system, which is found mostly in continental Europe and its former colonies, was introduced in the 19th century by Napoleon and Bismarck. La Porta et al. (1999) argue that the civil law system is "largely legislature created and is focused on discovering a just solution to a dispute (often from the point of view of the State), rather than on following a just procedure that protects individuals against the State". Civil law systems have largely been an instrument of the State in expanding its power and "can be taken as a proxy for an intent to build institutions to further the power of the State" (La Porta et al., 1999; Treisman, 2000). Thus, a civil law tradition is associated with lower governance, less efficient governments, and higher levels of corruption (La Porta et al., 1999).

\subsubsection{Religion}

Religious practices have the potential "to shape national views regarding property rights, competition, and the role of State" (Beck et al., 2003, p. 151; Stulz \& Williamson, 2003; La Porta et al., 1999). "In religious traditions such as Protestantism, which arose in some versions as dissenting sects opposed to the State-sponsored religion, institutions of the church may play a role in monitoring and denouncing abuses by State officials" (Treisman 2000, p. 403). Since the Catholic and Muslim religions tend to limit the security of property rights and private contracting (Levine, 2005; Landes, 1998), these religions may be associated with lower government performance and higher corruption (La Porta et al., 1999). Moreover, Protestant countries have better creditor rights and less corruption (Stulz \& Williamson, 2003).

\subsubsection{Ethnolinguistic Fractionalization}

Corruption is an illegal contract which cannot be enforced by courts. Treisman (2000) argues that ethnic communities and networks may serve as one of the mechanisms to "enhance the credibility of the private partner's commitment. In ethnically divided societies, ethnic communities may provide cheap information about and even internal sanctions against those who betray their coethnics" (Treisman, 2000, p. 406). Therefore, corruption contracts are strengthened within ethnic communities (Treisman, 2000). La Porta et al. (1999) measure such fractionalization and find that higher levels of fractionalization are associated with worse property rights and regulation, lower government efficiency, and higher corruption.

\subsubsection{Political Freedom}

Free association, free press, and regular and open electoral contests can increase the likelihood of divulging corrupt activities. Higher political rights enhance the opportunity of detecting and punishing those who engage in corruption (Lederman et al., 2005). "Countries with more political competition have stronger public pressure against corruption - through laws, democratic elections, and even the independent press - and so are more likely to use government organizations that contain rather than maximize corruption proceeds" (Shleifer \& Vishny, 1993, p. 610). Moreover, Treisman (2007) finds that greater political rights are significantly related to lower perceived corruption.

\subsubsection{GDP per Capita}

Some authors suggest that the problem of corruption lies in the low salaries bureaucrats receive (Treisman, 2000). They argue that to reduce the level of corruption, the wages of bureaucrats and public servants should be raised. The literature empirically shows that wealthier countries are less likely to be corrupt. To measure the wealth of a nation, GDP per capita is a natural option. Ades and Di Tella (1999) use per capita GDP as a control for the wealth of a nation. 


\subsubsection{Former Colonies}

Acemoglu et al. (2001 \& 2002) emphasize the importance of institutions, shaped by a country's colonization model. Mauro (1997) argues that it is difficult for countries that have been colonized to develop efficient institutions. Former colonies are considered less likely to have developed efficient and transparent local institutions because the colonizers' institution models "overlapped (and sometimes clashed) with previously existing informal institutions, fostering social fractionalization and hindering the mobility and social change required by the market" (Alonso, 2007, p. 71). Thus, the countries that have been colonized in the past are more corrupt.

\subsubsection{Oil Exporter Countries}

Leite and Weidmann (1999) present a model where economies abundant in natural resources show higher levels of corruption. They find that higher levels of natural resources are positively related to higher levels of corruption. Sachs and Warner (1995) show that natural resource economies grow more slowly, and they suggest this is due in part to a lower efficiency of government. Ades and Di Tella (1999) also find evidence that oil and corruption are correlated.

\subsubsection{Government Expenditure}

Many contemporary academic works suggest that a large public sector, measured by government expenditure, fosters corruption. The larger the role the government plays in the market - as producer and/or consumer - the greater its capacity to engage in corrupt activity, ceteris paribus. As a rule, "the larger the relative size and scope of the public sector, the greater will be the proportion of corrupt acts" (Scott, 1972, p. 9).

\subsubsection{Size}

To control for the size of the country, we use its population because several papers suggest a relationship between population and government efficiency (Treisman, 2000; Knack \& Azfar, 2003).

\section{Data}

Our analysis is based on panel dataset of measures of corruption and its potential determinants in 50 countries. We estimate equations explaining corruption perceptions index as a function of openness to trade and country characteristics. Since we are combining a number of datasets, we have different numbers of observations for different variables. This makes the panel dataset unbalanced. The data spans from 1998 to 2013. The M\&A data is downloaded from Thomson Reuters SDC mergers and acquisitions database. We use Corruption perceptions index from Transparency International as our main corruption measure. We use other databases to download the other variables. Appendix A summarizes the definition and sources of all the variables used in this article with their expected signs. Since we have 16 years of observations and 50 countries, the total number of potential observations is $800(16 \times 50)$.

\section{Results and Discussion}

\subsection{Descriptive Statistics}

Table 1 presents summary statistics for the corruption index, M\&A activity measures and the control variables. Corruption perceptions index ranges from 0 to 10 and has the maximum of 10 and minimum of 1 in the sample data. CPI has a mean of 3.67 and standard deviation of 2.48, showing that most of the population's CPI is not far from the sample mean, indicating the severity of the problem of corruption in the world. For the measures of M\&A, total number per year has the maximum of 11,019 and total value per year has the maximum of 1,589,574 million dollars. Fifty-eight percent of the countries in the sample were a colony, 42 percent have a French legal origin, 24 percent are protestant, and 12 percent are oil exporters. 
Table 1. Summary statistics

\begin{tabular}{lllrrrr}
\hline Variable & Obs & Unit & Mean & Std. Dev. & Min & Max \\
\hline CPI & 793 & Between 0 and 10 & 5.66 & 2.48 & 1 & 10 \\
Domestic number per year & 800 & Count & 303.96 & 917.51 & 0 & 8709 \\
Domestic value per year & 800 & Million dollars & 25856.70 & 114292.90 & 0 & 1226334 \\
Cross-border number per year & 800 & Count & 180.48 & 332.66 & 0 & 2580 \\
Cross-border value per year & 800 & Million dollars & 19977.50 & 49955.32 & 0 & 492604.8 \\
Total number per year & 800 & Count & 484.43 & 1228.60 & 0 & 11019 \\
Total value per year & 800 & Million dollars & 45834.19 & 156018.80 & 0 & 1589574 \\
Per capita GDP & 799 & Dollars & 19978.99 & 19031.53 & 274 & 100819 \\
Former colony & 800 & Dummy & 0.58 & 0.49 & 0 & 1 \\
EF & 800 & Between 0 and 1 & 0.26 & 0.25 & 0.002 & 0.8567 \\
Oil exporter & 800 & Dummy & 0.12 & 0.33 & 0 & 1 \\
Government expenditure & 790 & Million dollars & 16.42 & 5.35 & 2.047121 & 31.59911 \\
Population & 799 & Million & 97.00 & 238.00 & 3.29 & 1360.00 \\
Political rights & 784 & Between 1 to 7 & 2.32 & 1.74 & 1 & 7 \\
French legal origin & 800 & Dummy & 0.42 & 0.49 & 0 & 1 \\
Primary religion & 800 & Dummy & 0.24 & 0.43 & 0 & 1 \\
\hline
\end{tabular}

Table 2 presents the pairwise correlations matrix of dependent and independent variables. The two variables Cross-border number per year and Cross-border value per year are highly correlated. Their correlation coefficient is 0.9043 , which confirms that the two variables actually measure the same thing. GDP per capita has a slightly high correlation with CPI, which is normal since GDP per capita is linked to corruption in the literature. Apart from the aforementioned variables, all other pairwise correlations between the independent variables are not high enough to cause a possible multicollinearity problem in the model. The correlation coefficients between main variables (total value per year and total number per year) and CPI are positive and significant, which shows that lower levels of corruption (higher index) are associated with more M\&A activity.

Table 2. Pairwise correlation matrix

\begin{tabular}{|c|c|c|c|c|c|c|c|c|c|c|c|c|}
\hline Correlation Matrix & CPI & $\begin{array}{l}\text { Number } \\
\text { per year }\end{array}$ & $\begin{array}{c}\text { Value Per } \\
\text { Year }\end{array}$ & $\begin{array}{c}\text { Per Capita } \\
\text { GDP }\end{array}$ & $\begin{array}{l}\text { Former } \\
\text { colony }\end{array}$ & $\mathrm{EF}$ & $\begin{array}{c}\text { Oil } \\
\text { exporter }\end{array}$ & $\begin{array}{l}\text { Government } \\
\text { Expenditure }\end{array}$ & Population & $\begin{array}{c}\text { Political } \\
\text { rights }\end{array}$ & $\begin{array}{c}\text { French legal } \\
\text { origin }\end{array}$ & $\begin{array}{l}1 \text { Primary } \\
\text { religion }\end{array}$ \\
\hline CPI & 1.0000 & & & & & & & & & & & \\
\hline Cross-border & $0.3915^{* *}$ & 1.0000 & & & & & & & & & & \\
\hline \multicolumn{13}{|l|}{ Number per year } \\
\hline $\begin{array}{l}\text { Cross-border } \\
\text { value per year }\end{array}$ & $0.3010 * *$ & $0.9043 * *$ & 1.0000 & & & & & & & & & \\
\hline Per capita GDP & $0.7891 * *$ & $0.4239 * *$ & $0.3202 * *$ & 1.0000 & & & & & & & & \\
\hline Former colony & $-0.4469 * *$ & $-0.3543 * *$ & $-0.3140 * *$ & $-0.5422 * *$ & 1.0000 & & & & & & & \\
\hline Ethnolinguistic & $-0.4722 * *$ & $-0.1514 * *$ & $-0.1347 * *$ & $-0.4247 * *$ & $0.3852 * *$ & 1.0000 & & & & & & \\
\hline \multicolumn{13}{|l|}{ Fractionalization } \\
\hline Oil exporter & $-0.2963 * *$ & $-0.1632 * *$ & $-0.1258 * *$ & $-0.1109 * *$ & $0.1895^{* *}$ & -0.0388 & 1.0000 & & & & & \\
\hline $\begin{array}{l}\text { Government } \\
\text { expenditure }\end{array}$ & $0.5303 * *$ & $0.1915^{* *}$ & $0.1414 * *$ & $0.5022 * *$ & $-0.5216^{* *}$ & $-0.3995 * *$ & $-0.1839 * *$ & 1.0000 & & & & \\
\hline Population & $-0.2662 * *$ & $0.1038 * *$ & $0.0699 * *$ & $-0.2285^{* *}$ & -0.0388 & $0.2261 * *$ & $-0.0719 * *$ & $-0.1952 * *$ & 1.0000 & & & \\
\hline Political rights & $-0.6048 * *$ & $-0.2984 * *$ & $-0.2444 * *$ & $-0.5760 * *$ & $0.3921 * *$ & $0.3467 * *$ & $0.2647 * *$ & $-0.4659 * *$ & $0.2935^{* *}$ & 1.0000 & & \\
\hline French legal origin & $-0.3538 * *$ & $-0.2273 * *$ & $-0.1539 * *$ & $-0.3079 * *$ & 0.0673 & $-0.2285^{* *}$ & $0.1846^{* *}$ & $-0.0930 * *$ & $-0.1529 * *$ & 0.0011 & 1.0000 & \\
\hline Primary religion & $0.4210^{* *}$ & $0.3915^{* *}$ & $0.3239 * *$ & $0.3774 * *$ & $-0.1860^{* *}$ & $-0.1007 * *$ & -0.0634 & $0.3766^{* *}$ & $-0.1069 * *$ & $-0.3160 * *$ & $-0.4782 * *$ & 1.0000 \\
\hline
\end{tabular}

Figure 1 plots the number (Panel A) and dollar value (Panel B) of cross-border deals over the sample period. Both panels show similar patterns. Cross-border M\&A activity increases throughout the 1990s, declines after the stock market crash of 2000, then increases from 2002 until 2007, declines with the economic recession of 2007, and stays volatile until 2013. Erel et al. (2012) find the same pattern in M\&A activity. 
Panel A (Total number of cross-border deals)

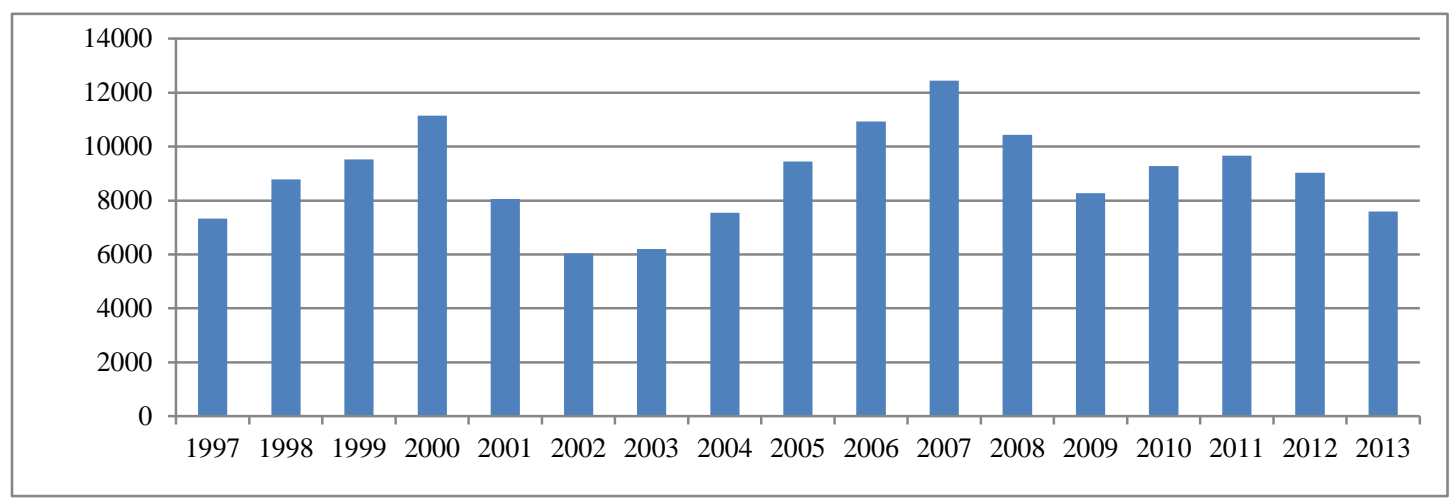

Panel B (Total value of cross-border deals in \$million)

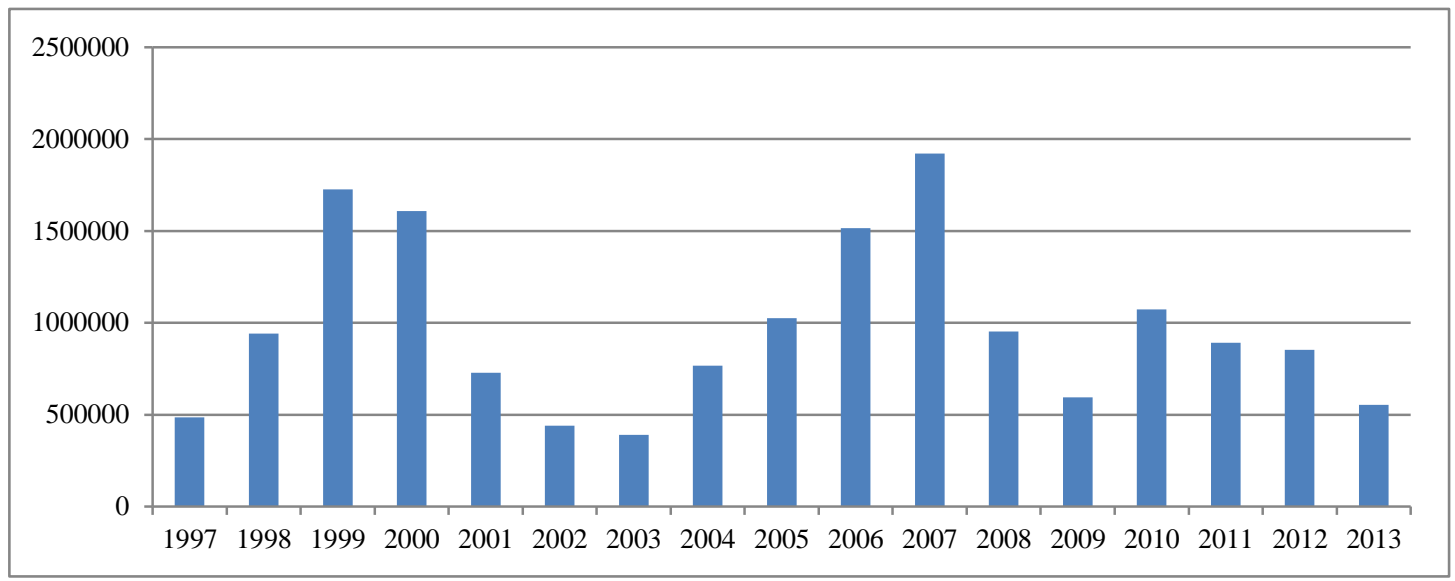

Figure 1. Cross-border M\&A activity

\subsection{Regression Results}

To evaluate the effects of openness to trade and competition on corruption, we use a multivariate regression framework. Our goal is to analyze how M\&A activity can affect the level of corruption in the host country over time. Because we are interested in the effects of M\&A activity on corruption and how changes in M\&A activity can influence corruption, we use panel analysis. Our dependent variable is the CPI which measures the corruption perception level over the entire sample period. Our independent variables are the M\&A activity measures (number and dollar amount per year, domestic and cross-border) and several determinants of corruption suggested in the literature as control variables.

Table 3 presents random effect panel regression estimates of the determinants of corruption as represented by proxies of openness to trade and competition (domestic, cross-border and total M\&A activity). The results are revealing. All measures of M\&A activity show significant and positive association to CPI, meaning that M\&A activity decrease the level of corruption in host countries. An increase in the level of M\&A activity leads to an increase in the corruption index, which means less corruption. Coefficients of both cross-border number and cross-border value per year are significant and positive, showing that cross-border mergers can increase competition and spread the norms and cultures from the other side of the border. Domestic measures also show a positive and significant relation to corruption which shows that domestic mergers also play a big role in decreasing corruption by increasing competition. Coefficients of total activity in a country are greater than cross-border and domestic activities alone. This means that both cross-border and domestic mergers are important in increasing competition and, as a result, reducing corruption. 
Table 3. Panel analysis of the determinants of corruption

\begin{tabular}{|c|c|c|c|c|c|c|c|}
\hline & CPI & $\mathrm{CPI}$ & CPI & $\mathrm{CPI}$ & CPI & CPI & $\mathrm{CPI}$ \\
\hline & $(1)$ & $(2)$ & (3) & $(4)$ & $(5)$ & $(6)$ & $(7)$ \\
\hline $\begin{array}{l}\text { Log cross-border value per } \\
\text { year }_{(\mathrm{t}-1)}\end{array}$ & $\begin{array}{r}0.056^{* * * *} \\
(3.52)\end{array}$ & & & & & & \\
\hline $\begin{array}{l}\text { Log cross-border number } \\
\text { per year }_{(t-1)}\end{array}$ & & $\begin{array}{r}0.182^{* * * *} \\
(3.85)\end{array}$ & & & & & \\
\hline $\begin{array}{l}\text { Log domestic value per } \\
\operatorname{year}_{(t-1)}\end{array}$ & & & $\begin{array}{r}0.034^{* *} \\
(2.15)\end{array}$ & & & & \\
\hline $\begin{array}{l}\text { Log domestic number per } \\
\operatorname{year}_{(t-1)}\end{array}$ & & & & $\begin{array}{r}0.146^{* * * *} \\
(3.1)\end{array}$ & & & \\
\hline Log Total value per year $r_{(t-1)}$ & & & & & $\begin{array}{r}0.057 * * * \\
(2.78)\end{array}$ & & \\
\hline $\begin{array}{l}\text { Log Total number per } \\
\operatorname{year}_{(\mathrm{t}-1)}\end{array}$ & & & & & & $\begin{array}{r}0.206^{* * * *} \\
(3.67)\end{array}$ & \\
\hline Former colony & $\begin{array}{r}-0.889 * * \\
(-2.21)\end{array}$ & $\begin{array}{r}-0.801 * * \\
(-2.09)\end{array}$ & $\begin{array}{r}-0.942 * * \\
(-2.3)\end{array}$ & $\begin{array}{r}-0.846 * * \\
(-2.17)\end{array}$ & $\begin{array}{r}-0.892 * * \\
(-2.21)\end{array}$ & $\begin{array}{r}-0.808 * * \\
(-2.13)\end{array}$ & $\begin{array}{r}-0.929 * * \\
(-2.25)\end{array}$ \\
\hline Log GDP per capita $(t-1)$ & $\begin{array}{r}0.172 * * \\
(2.17)\end{array}$ & $\begin{array}{r}0.149 * \\
(1.76)\end{array}$ & $\begin{array}{r}0.168^{*} \\
(1.93)\end{array}$ & $\begin{array}{l}0.127 \\
(1.52)\end{array}$ & $\begin{array}{r}0.173 * * \\
(2.1)\end{array}$ & $\begin{array}{l}0.107 \\
(1.31)\end{array}$ & $\begin{array}{r}0.242 * * * \\
(2.83)\end{array}$ \\
\hline $\mathrm{EF}$ & $\begin{array}{r}-2.177 * * \\
(-2.47)\end{array}$ & $\begin{array}{r}-2.029 * * \\
(-2.45)\end{array}$ & $\begin{array}{r}-2.087 * * \\
(-2.27)\end{array}$ & $\begin{array}{r}-2.116^{* *} \\
(-2.5)\end{array}$ & $\begin{array}{r}-2.108 * * \\
(-2.39)\end{array}$ & $\begin{array}{r}-2.027 * * \\
(-2.49)\end{array}$ & $\begin{array}{r}-2.112 * * \\
(-2.31)\end{array}$ \\
\hline Oil Exporter & $\begin{array}{r}-1.184 * * * \\
(-3.12)\end{array}$ & $\begin{array}{r}-1.05 * * * \\
(-2.8)\end{array}$ & $\begin{array}{r}-1.125 * * * \\
(-2.87)\end{array}$ & $\begin{array}{r}-1.063 * * * \\
(-2.73)\end{array}$ & $\begin{array}{r}-1.156 * * * \\
(-3)\end{array}$ & $\begin{array}{r}-1.02 * * * \\
(-2.7)\end{array}$ & $\begin{array}{r}-1.223 * * * \\
(-3.09)\end{array}$ \\
\hline Log Government & 0.047 & 0.063 & 0.053 & $\begin{array}{r}0.03 \\
58\end{array}$ & 0.05 & 0.055 & 0.053 \\
\hline Expenditure & $(0.88)$ & (1.13) & $(0.95)$ & $(0.58)$ & $(0.91)$ & $(0.97)$ & $\begin{array}{r}(0.94) \\
0\end{array}$ \\
\hline Log population & $\begin{array}{r}-0.705 * * * \\
(-6.24)\end{array}$ & $\begin{array}{r}-0.739 * * * \\
(-6.92)\end{array}$ & $\begin{array}{r}-0.752 * * * \\
(-6.28)\end{array}$ & $\begin{array}{r}-0.766^{* * *} \\
(-6.39)\end{array}$ & $\begin{array}{r}-0.722 * * * \\
(-6.33)\end{array}$ & $\begin{array}{r}-0.784 * * * \\
(-6.98)\end{array}$ & $\begin{array}{r}-0.683 * * * \\
(-5.8)\end{array}$ \\
\hline Political rights & $\begin{array}{r}-0.083 * \\
(-1.7)\end{array}$ & $\begin{array}{r}-0.076^{*} \\
(-1.68)\end{array}$ & $\begin{array}{r}-0.094 * \\
(-1.8)\end{array}$ & $\begin{array}{r}-0.085^{*} \\
(-1.78)\end{array}$ & $\begin{array}{r}-0.089 * \\
(-1.86)\end{array}$ & $\begin{array}{r}-0.075 \\
(-1.64)\end{array}$ & $\begin{array}{r}-0.082 * \\
(-1.8)\end{array}$ \\
\hline French legal origin & $\begin{array}{r}-1.241 * * * \\
(-2.78)\end{array}$ & $\begin{array}{r}-1.195^{* * * *} \\
(-2.93)\end{array}$ & $\begin{array}{r}-1.231 * * * \\
(-2.68)\end{array}$ & $\begin{array}{r}-1.179 * * * \\
(-2.73)\end{array}$ & $\begin{array}{r}-1.242 * * * \\
(-2.79)\end{array}$ & $\begin{array}{r}-1.165^{* * *} * \\
(-2.84)\end{array}$ & $\begin{array}{r}-1.237 * * * \\
(-2.71)\end{array}$ \\
\hline Primary religion & $\begin{array}{r}0.757 \\
(1.49)\end{array}$ & $\begin{array}{r}0.674 \\
(1.44)\end{array}$ & $\begin{array}{r}0.736 \\
(1.4)\end{array}$ & $\begin{array}{r}0.686 \\
(1.44)\end{array}$ & $\begin{array}{r}0.738 \\
(1.47)\end{array}$ & $\begin{array}{r}0.66 \\
(1.44)\end{array}$ & $\begin{array}{l}0.784 \\
(1.53)\end{array}$ \\
\hline Constant & $\begin{array}{r}17.357 * * * \\
(8.09)\end{array}$ & $\begin{array}{r}17.696^{* * * *} \\
(8.25)\end{array}$ & $\begin{array}{r}18.414 * * * \\
(7.98)\end{array}$ & $\begin{array}{r}18.667 * * * \\
(8.07)\end{array}$ & $\begin{array}{r}17.594 * * * \\
(8.03)\end{array}$ & $\begin{array}{r}18.624 * * * \\
(8.51)\end{array}$ & $\begin{array}{r}16.767 * * * \\
(7.34)\end{array}$ \\
\hline Observations & 753 & 768 & 711 & 753 & 763 & 773 & 775 \\
\hline $\mathrm{R}^{2}$ & 0.75 & 0.78 & 0.74 & 0.77 & 0.75 & 0.78 & 0.74 \\
\hline
\end{tabular}

Note. This table presents estimates of panel regressions of the effects of cross-border and domestic mergers and acquisitions on corruption. The dependent variable is corruption perception index (CPI) for the year $t$ and country i. To control for endogeneity, some independent variables are lagged one year. Heteroskedasticity-corrected t-statistics are in parentheses. The variable definitions are provided in Appendix A. $* * *, * *$, and $*$ denote statistical significance at the $1 \%, 5 \%$, and $10 \%$ levels, respectively.

Most of the control variables are significant and have the expected sign. Former colony has a negative and significant coefficient in all the models. Whilst higher values of CPI mean that the country is less corrupt, these results confirm the literature stating that former colonies cannot develop efficient institutions and are more corrupt (lower CPI). The coefficient of Log per capita GDP is significant for most of the model specifications. This shows that GDP per capita and corruption are negatively associated and higher GDP per capita is linked to less corruption in a country. As predicted in the literature, Ethnolinguistic fractionalisation is also significant and negative which shows that more ethnolinguistic fractionalisation in a country is linked to higher corruption. Moreover, Oil exporter dummy is strongly significant and negative in all the M\&A measures. As stated before, oil exporter countries tend to be more corrupt. Contrary to what is predicted in the literature, the coefficients of government expenditure are not significant in any M\&A measures. Political rights coefficients are also significant and negative. This shows and increase in the variable (being less politically free) will decrease the CPI (being more corrupt). Thus, higher political freedom in country is linked to less corruption in a country. French legal origins dummy is also significant and negative stating that countries with civil law systems tend to 
be more corrupt. Interestingly primary religion is not significant in any M\&A measures contrary to what is reported in the literature.

\subsection{Robustness Checks}

In this section, we use different approaches to test the robustness of the results.

\subsubsection{Alternative Corruption Measure}

To gain robustness, we use an alternate measure of corruption in the analysis. The Political Risk Services corruption index (ICRG) is another measure of perceived corruption which is widely used in the literature. This is particularly important since corruption is measured through surveys on the respondent's subjective perceived level of corruption. Using different indices of corruption reduces the risk of a respondent's misjudgment on their perceived level of corruption. The ICRG has a correlation coefficient of 0.8864 with CPI. Table 1.4 presents random effect panel regression estimates of the determinants of corruption. The dependent variable is ICRG and independent variables are measures of M\&A activity.

Table 4. Robustness tests, alternate corruption measure

\begin{tabular}{|c|c|c|c|c|c|c|}
\hline & ICRG & ICRG & ICRG & ICRG & ICRG & ICRG \\
\hline Log cross-border value per year(t-1) & $\begin{array}{r}0.05 * * * \\
(2.78)\end{array}$ & & & & & \\
\hline Log Cross-border number per year(t-1) & & $\begin{array}{l}0.13 * \\
(1.68)\end{array}$ & & & & \\
\hline Log Domestic value per year(t-1) & & & $\begin{array}{l}-0.007 \\
(-0.47)\end{array}$ & & & \\
\hline Log Domestic number per year(t-1) & & & & $\begin{array}{r}0.128^{* * * *} \\
(2.89)\end{array}$ & & \\
\hline Log Total value per year(t-1) & & & & & $\begin{array}{r}0.033^{*} \\
(1.95)\end{array}$ & \\
\hline Log Total number per year(t-1) & & & & & & $\begin{array}{r}0.15^{* *} \\
(2.32)\end{array}$ \\
\hline Former colony & $\begin{array}{l}-0.396 \\
(-1.57)\end{array}$ & $\begin{array}{l}-0.339 \\
(-1.37)\end{array}$ & $\begin{array}{l}-0.437 \\
(-1.64)\end{array}$ & $\begin{array}{l}-0.369 \\
(-1.49)\end{array}$ & $\begin{array}{l}-0.421 \\
(-1.64)\end{array}$ & $\begin{array}{l}-0.358 \\
(-1.46)\end{array}$ \\
\hline Log GDP per Capita(t-1) & $\begin{array}{l}0.079 \\
(0.74)\end{array}$ & $\begin{array}{r}0.05 \\
(0.41)\end{array}$ & $\begin{array}{l}0.126 \\
(1.12)\end{array}$ & $\begin{array}{l}0.029 \\
(0.26)\end{array}$ & $\begin{array}{l}0.083 \\
(0.75)\end{array}$ & $\begin{array}{l}0.016 \\
(0.13)\end{array}$ \\
\hline EF & $\begin{array}{l}-0.862 \\
(-1.65)\end{array}$ & $\begin{array}{l}-0.726 \\
(-1.54)\end{array}$ & $\begin{array}{l}-0.785 \\
(-1.54)\end{array}$ & $\begin{array}{l}-0.745 \\
(-1.62)\end{array}$ & $\begin{array}{l}-0.807 \\
(-1.56)\end{array}$ & $\begin{array}{l}-0.716 \\
(-1.57)\end{array}$ \\
\hline Oil Exporter & $\begin{array}{l}-0.245 \\
(-1.42)\end{array}$ & $\begin{array}{l}-0.195 \\
(-1.32)\end{array}$ & $\begin{array}{r}-0.332 * * \\
(-2.02)\end{array}$ & $\begin{array}{l}-0.169 \\
(-0.98)\end{array}$ & $\begin{array}{l}-0.253 \\
(-1.44)\end{array}$ & $\begin{array}{l}-0.173 \\
(-1.12)\end{array}$ \\
\hline Log Government expenditure & $\begin{array}{l}-0.072 \\
(-1.19)\end{array}$ & $\begin{array}{l}-0.044 \\
(-0.69)\end{array}$ & $\begin{array}{r}-0.138 * * \\
(-2.13)\end{array}$ & $\begin{array}{l}-0.074 \\
(-1.26)\end{array}$ & $\begin{array}{l}-0.064 \\
(-1.02)\end{array}$ & $\begin{array}{r}-0.047 \\
(-0.73)\end{array}$ \\
\hline Log population & $\begin{array}{r}-0.31 * * * \\
(-3.61)\end{array}$ & $\begin{array}{r}-0.338 * * * \\
(-3.58)\end{array}$ & $\begin{array}{r}-0.289 * * * \\
(-3.38)\end{array}$ & $\begin{array}{r}-0.371 * * * \\
(-4.42)\end{array}$ & $\begin{array}{r}-0.317 * * * \\
(-3.65)\end{array}$ & $\begin{array}{r}-0.376^{* * * *} \\
(-4.01)\end{array}$ \\
\hline Political rights & $\begin{array}{r}-0.168 * * * \\
(-2.74)\end{array}$ & $\begin{array}{r}-0.169 * * * \\
(-2.82)\end{array}$ & $\begin{array}{r}-0.161 * * \\
(-2.52)\end{array}$ & $\begin{array}{r}-0.163 * * * \\
(-2.6)\end{array}$ & $\begin{array}{r}-0.171 * * * \\
(-2.69)\end{array}$ & $\begin{array}{r}-0.158^{* * *} * \\
(-2.66)\end{array}$ \\
\hline French legal origin & $\begin{array}{l}-0.258 \\
(-0.95)\end{array}$ & $\begin{array}{l}-0.219 \\
(-0.88)\end{array}$ & $\begin{array}{l}-0.255 \\
(-0.93)\end{array}$ & $\begin{array}{r}-0.19 \\
(-0.76)\end{array}$ & $\begin{array}{l}-0.257 \\
(-0.94)\end{array}$ & $\begin{array}{r}-0.19 \\
(-0.78)\end{array}$ \\
\hline Primary religion & $\begin{array}{r}0.587 \\
(1.95)\end{array}$ & $\begin{array}{r}0.578 * * \\
(2.1)\end{array}$ & $\begin{array}{r}0.685^{* *} * \\
(2.33)\end{array}$ & $\begin{array}{r}0.58 * * \\
(2.13)\end{array}$ & $\begin{array}{r}0.613 * * \\
(2.09)\end{array}$ & $\begin{array}{r}0.582 * * \\
(2.16)\end{array}$ \\
\hline Constant & $\begin{array}{r}8.544 * * * \\
(3.93)\end{array}$ & $\begin{array}{r}9.024 * * * \\
(3.8)\end{array}$ & $\begin{array}{r}8.384 * * * \\
(3.7)\end{array}$ & $\begin{array}{r}9.872 * * * \\
(4.42)\end{array}$ & $\begin{array}{r}8.739 * * * \\
(3.94)\end{array}$ & $\begin{array}{r}9.775^{* * * *} \\
(4.05)\end{array}$ \\
\hline Observations & 759 & 775 & 716 & 759 & 770 & 775 \\
\hline $\mathrm{R} 2$ & 0.64 & 0.66 & 0.61 & 0.66 & 0.63 & 0.78 \\
\hline
\end{tabular}

Note. This table presents estimates of random effect model of cross-border and domestic mergers and acquisitions activity. The dependent variable is Political Risk Services corruption index (ICRG) for the year $t$ and country i. To control for endogeneity, some independent variables are lagged one year. Heteroskedasticity-corrected $t$-statistics are in parentheses. The variable definitions are provided in Appendix A. $* * *, * *$, and $*$ denote statistical significance at the $1 \%, 5 \%$, and $10 \%$ levels, respectively. 
The results are similar to Table 3 and confirm our results. The coefficients of both cross-border number and value per year are positive and statistically significant. Domestic measures show a positive and significant relation to ICRG in at least one measure, and the coefficients of both total number and value per year are significant. Former colony, GPD per capita, EF and French legal origin do not show significance in any measures, but the coefficients of primary religion are statistically significant in most of the measures.

\subsubsection{Longer Lags}

Curing corruption is not easy. Corruption is rooted in the quality of a country's institutions, and institutional norms and policies may take years to change. As a result, we use longer lags in the second robustness checks to see if M\&A activity from previous years has an effect on corruption. we use 2 year and 5 year lags in Table 5, which presents estimates of Pooled OLS model of cross-border and domestic merger and acquisition activity.

Table 5. Robustness tests, longer lags

\begin{tabular}{|c|c|c|c|c|c|c|}
\hline Lagged 2 years & $\mathrm{CPI}$ & $\mathrm{CPI}$ & $\mathrm{CPI}$ & $\mathrm{CPI}$ & $\mathrm{CPI}$ & $\mathrm{CPI}$ \\
\hline Log cross-border value per year(t-2) & $\begin{array}{r}0.266^{* * * *} \\
(9.48)\end{array}$ & & & & & \\
\hline Log Cross-border number per year(t-2) & & $\begin{array}{r}0.702 * * * \\
(13.53)\end{array}$ & & & & \\
\hline Log Domestic value per year(t-2) & & & $\begin{array}{r}0.173 * * * \\
(6.24)\end{array}$ & & & \\
\hline Log Domestic number per year(t-2) & & & & $\begin{array}{r}0.52 * * * \\
(11.49)\end{array}$ & & \\
\hline Log Total value per year(t-2) & & & & & $\begin{array}{r}0.271 * * * \\
(8.33)\end{array}$ & \\
\hline Log Total number per year(t-2) & & & & & & $\begin{array}{r}0.68^{* * * *} \\
(12.93)\end{array}$ \\
\hline Control Variables & Yes & Yes & Yes & Yes & Yes & Yes \\
\hline Observations & 750 & 768 & 709 & 752 & 760 & 773 \\
\hline R2 & 0.82 & 0.86 & 0.81 & 0.84 & 0.83 & 0.85 \\
\hline Lagged 5 years & CPI & CPI & $\mathrm{CPI}$ & CPI & CPI & $\mathrm{CPI}$ \\
\hline Log cross-border value per year(t-5) & $\begin{array}{r}0.221 * * * \\
(8.04)\end{array}$ & & & & & \\
\hline Log Cross-border number per year(t-5) & & $\begin{array}{r}0.672 * * * \\
(13.48)\end{array}$ & & & & \\
\hline Log Domestic value per year(t-5) & & & $\begin{array}{r}0.168^{* * * *} \\
(6.27)\end{array}$ & & & \\
\hline Log Domestic number per year(t-5) & & & & $\begin{array}{r}0.459 * * * \\
(11.59)\end{array}$ & & \\
\hline Log Total value per year(t-5) & & & & & $\begin{array}{r}0.238 * * * \\
(7.55)\end{array}$ & \\
\hline Log Total number per year(t-5) & & & & & & $\begin{array}{r}0.611 * * * \\
(12.91)\end{array}$ \\
\hline Control Variables & Yes & Yes & Yes & Yes & Yes & Yes \\
\hline Observations & 741 & 761 & 704 & 746 & 755 & 770 \\
\hline $\mathrm{R} 2$ & 0.82 & 0.85 & 0.81 & 0.83 & 0.82 & 0.84 \\
\hline
\end{tabular}

Note. This table presents estimates of Pooled OLS model of cross-border and domestic mergers and acquisition activity. The dependent variable is corruption perception index (CPI) for the year $t$ and country i. To control for endogeneity, some independent variables are lagged. Heteroskedasticity-corrected $\mathrm{t}$-statistics are in parentheses. The variable definitions are provided in Appendix A. ***, **, and $*$ denote statistical significance at the $1 \%, 5 \%$, and $10 \%$ levels, respectively.

All measures of lagged M\&A activity show significant and positive association to CPI, meaning that these activities decrease the level of corruption in host countries. The results of this table further confirm the results.

\subsubsection{Random Effects vs. Fixed Effect and Pooled OLS}

To check the validity of the random effect model, Table 6 compares fixed effect and pooled OLS results. 
Table 6. Robustness tests, OLS vs. fixed effect

\begin{tabular}{|c|c|c|c|c|c|c|}
\hline & \multicolumn{6}{|c|}{ Pooled OLS } \\
\hline & CPI & CPI & CPI & CPI & CPI & CPI \\
\hline $\begin{array}{l}\text { Log cross-border value per } \\
\operatorname{year}_{(\mathrm{t}-1)}\end{array}$ & $\begin{array}{l}0.306^{* * * *} \\
(10.9)\end{array}$ & & & & & \\
\hline $\begin{array}{l}\text { Log Cross-border number per } \\
\operatorname{year}_{(\mathrm{t}-1)}\end{array}$ & & $\begin{array}{l}0.779 * * * \\
(15.3)\end{array}$ & & & & \\
\hline Log Domestic value per year ${ }_{(\mathrm{t}-1)}$ & & & $\begin{array}{l}0.156^{* * * *} \\
(5.53)\end{array}$ & & & \\
\hline Log Domestic number per year ${ }_{(\mathrm{t}-1)}$ & & & & $\begin{array}{l}0.557 * * * \\
(12.21)\end{array}$ & & \\
\hline Log Total value per year ${ }_{(t-1)}$ & & & & & $\begin{array}{l}0.293 * * * \\
(8.95)\end{array}$ & \\
\hline Log Total number per year ${ }_{(\mathrm{t}-1)}$ & & & & & & $\begin{array}{l}0.745 * * * \\
(13.93)\end{array}$ \\
\hline Former colony & $\begin{array}{l}-0.154 \\
(-1.51)\end{array}$ & $\begin{array}{l}-0.123 \\
(-1.41)\end{array}$ & $\begin{array}{l}-0.27 * * \\
(-2.43)\end{array}$ & $\begin{array}{l}-0.178 * * \\
(-1.84)\end{array}$ & $\begin{array}{l}-0.219 \\
(-2.09)\end{array}$ & $\begin{array}{l}-0.168 * \\
(-1.85)\end{array}$ \\
\hline Log GDP per Capita $(\mathrm{t}-1)$ & $\begin{array}{l}0.475 * * * \\
(6.58)\end{array}$ & $\begin{array}{l}0.09 \\
(1.18)\end{array}$ & $\begin{array}{l}0.691 * * * \\
(8.27)\end{array}$ & $\begin{array}{l}0.259 * * * \\
(3.21)\end{array}$ & $\begin{array}{l}0.47 * * * \\
(5.7)\end{array}$ & $\begin{array}{l}0.052 \\
(0.62)\end{array}$ \\
\hline $\mathrm{EF}$ & $\begin{array}{l}-0.827^{* * * *} \\
(-3.63)\end{array}$ & $\begin{array}{l}-1.165^{* * * *} \\
(-5.59)\end{array}$ & $\begin{array}{l}-0.476^{* *} \\
(-1.96)\end{array}$ & $\begin{array}{l}-1.017 * * * * \\
(-4.73)\end{array}$ & $\begin{array}{l}-0.739 * * * \\
(-3.24)\end{array}$ & $\begin{array}{l}-1.131 * * * \\
(-5.45)\end{array}$ \\
\hline Oil Exporter & $\begin{array}{l}-0.69 * * * \\
(-6.06)\end{array}$ & $\begin{array}{l}-0.333 * * * \\
(-3.02)\end{array}$ & $\begin{array}{l}-0.613^{* * * *} \\
(-4.85)\end{array}$ & $\begin{array}{l}-0.334 * * * \\
(-2.88)\end{array}$ & $\begin{array}{l}-0.6 * * * \\
(-5.29)\end{array}$ & $\begin{array}{l}-0.273 * * \\
(-2.42)\end{array}$ \\
\hline Log Government expenditure & $\begin{array}{l}0.134 \\
(1.51)\end{array}$ & $\begin{array}{l}0.066 \\
(0.76)\end{array}$ & $\begin{array}{l}0.092 \\
(0.92)\end{array}$ & $\begin{array}{l}0.069 \\
(0.85)\end{array}$ & $\begin{array}{l}0.122 \\
(1.38)\end{array}$ & $\begin{array}{l}0.075 \\
(0.91)\end{array}$ \\
\hline Log population & $\begin{array}{l}-0.66^{* * * *} \\
(-17.18)\end{array}$ & $\begin{array}{l}-0.837 * * * \\
(-19.16)\end{array}$ & $\begin{array}{l}-0.579 * * * \\
(-12.02)\end{array}$ & $\begin{array}{l}-0.847 * * * \\
(-17.19)\end{array}$ & $\begin{array}{l}-0.681 * * * \\
(-14.82)\end{array}$ & $\begin{array}{l}-0.921 * * * \\
(-18.65)\end{array}$ \\
\hline Political rights & $\begin{array}{l}-0.075^{* *} \\
(-2.15)\end{array}$ & $\begin{array}{l}-0.082 * * \\
(-2.74)\end{array}$ & $\begin{array}{l}-0.069 * * \\
(-1.82)\end{array}$ & $\begin{array}{l}-0.095^{* * * *} \\
(-2.67)\end{array}$ & $\begin{array}{l}-0.083^{* *} \\
(-2.37)\end{array}$ & $\begin{array}{l}-0.091 * * * \\
(-2.81)\end{array}$ \\
\hline French legal origin & $\begin{array}{l}-1.115^{* * * *} \\
(-11.35)\end{array}$ & $\begin{array}{l}-1.008^{* * * *} \\
(-11.37)\end{array}$ & $\begin{array}{l}-1.046^{* * * *} \\
(-10.17)\end{array}$ & $\begin{array}{l}-0.937 * * * \\
(-10.55)\end{array}$ & $\begin{array}{l}-1.108 * * * \\
(-11.48)\end{array}$ & $\begin{array}{l}-0.939 * * * \\
(-11.04)\end{array}$ \\
\hline Primary religion & $\begin{array}{l}0.376^{* * * *} \\
(3.48)\end{array}$ & $\begin{array}{l}0.201 * * * \\
(2.25)\end{array}$ & $\begin{array}{l}0.47 * * * \\
(4.18)\end{array}$ & $\begin{array}{l}0.19 * * \\
(1.99)\end{array}$ & $\begin{array}{l}0.376^{* * * *} \\
(3.56)\end{array}$ & $\begin{array}{l}0.172 * \\
(1.96)\end{array}$ \\
\hline Constant & $\begin{array}{l}10.799 * * * \\
(9.26)\end{array}$ & $\begin{array}{l}16.876^{* * * *} \\
(12.61)\end{array}$ & $\begin{array}{l}8.748 * * * \\
(6.01)\end{array}$ & $\begin{array}{l}16.422 * * * \\
(11.27)\end{array}$ & $\begin{array}{l}11.191 * * * \\
(8.4)\end{array}$ & $\begin{array}{l}18.275^{* * * *} \\
(12.7)\end{array}$ \\
\hline Observations & 753 & 768 & 711 & 753 & 763 & 773 \\
\hline \multirow[t]{3}{*}{$\mathrm{R}^{2}$} & 0.83 & 0.86 & 0.81 & 0.84 & 0.83 & 0.86 \\
\hline & Fixed Effec & & & & & \\
\hline & CPI & CPI & CPI & CPI & CPI & CPI \\
\hline $\begin{array}{l}\text { Log cross-border value per } \\
\text { year }_{(\mathrm{t}-1)}\end{array}$ & $\begin{array}{l}0.046^{* * * *} \\
(3.69)\end{array}$ & & & & & \\
\hline $\begin{array}{l}\text { Log Cross-border number per } \\
\operatorname{year}_{(\mathrm{t}-1)}\end{array}$ & & $\begin{array}{l}0.136^{* * * *} \\
(3.81)\end{array}$ & & & & \\
\hline Log Domestic value per year ${ }_{(\mathrm{t}-1)}$ & & & $\begin{array}{l}0.028 * * \\
(2.34)\end{array}$ & & & \\
\hline $\begin{array}{l}\text { Log Domestic number per } \\
\operatorname{year}_{(\mathrm{t}-1)}\end{array}$ & & & & $\begin{array}{l}0.117 * * * \\
(4.22)\end{array}$ & & \\
\hline Log Total value per year ${ }_{(\mathrm{t}-1)}$ & & & & & $\begin{array}{l}0.048 * * * \\
(3.5)\end{array}$ & \\
\hline Log Total number per year ${ }_{(\mathrm{t}-1)}$ & & & & & & $\begin{array}{l}0.165^{* * * *} \\
(4.71)\end{array}$ \\
\hline \multicolumn{7}{|l|}{ Former colony } \\
\hline Log GDP per Capita $(\mathrm{t}-1)$ & $\begin{array}{l}0.259 * * * \\
(3.93)\end{array}$ & $\begin{array}{l}0.268 * * * \\
(4.04)\end{array}$ & $\begin{array}{l}0.297 * * * \\
(4.53)\end{array}$ & $\begin{array}{l}0.219 * * * \\
(3.23)\end{array}$ & $\begin{array}{l}0.27 * * * \\
(4.1)\end{array}$ & $\begin{array}{l}0.225 * * * \\
(3.33)\end{array}$ \\
\hline \multicolumn{7}{|l|}{$\mathrm{EF}$} \\
\hline Log Government expenditure & $\begin{array}{l}0.03 \\
(0.67)\end{array}$ & $\begin{array}{l}0.044 \\
(0.96)\end{array}$ & $\begin{array}{l}0.04 \\
(0.79)\end{array}$ & $\begin{array}{l}0.017 \\
(0.37)\end{array}$ & $\begin{array}{l}0.034 \\
(0.76)\end{array}$ & $\begin{array}{l}0.038 \\
(0.85)\end{array}$ \\
\hline
\end{tabular}




\begin{tabular}{lllllll}
\hline Log population & $-1.73 * * *$ & $-1.822^{* * *}$ & $-2.043 * * *$ & $-1.61 * * *$ & $-1.743 * * *$ & $-1.784 * * *$ \\
& $(-4.15)$ & $(-4.46)$ & $(-4.87)$ & $(-4.01)$ & $(-4.28)$ & $(-4.47)$ \\
Political rights & $-0.067 * *$ & $-0.069 * *$ & $-0.092 * * *$ & $-0.078^{* * *}$ & $-0.081^{* * *}$ & $-0.071^{* *}$ \\
& $(-2.33)$ & $(-2.43)$ & $(-3.22)$ & $(-2.8)$ & $(-2.88)$ & $(-2.56)$ \\
French legal origin & & & & & \\
Primary religion & & & & & \\
Constant & $32.811^{* * *}$ & $34.073 * * *$ & $38.231 * * *$ & $31.094 * * *$ & $32.906 * * *$ & $33.591 * * *$ \\
& $(4.87)$ & $(5.15)$ & $(5.61)$ & $(4.78)$ & $(4.99)$ & $(5.2)$ \\
Observations & 753 & 768 & 711 & 753 & 763 & 773 \\
$\mathrm{R}^{2}$ & 0.41 & 0.45 & 0.44 & 0.46 & 0.43 & 0.46 \\
\hline
\end{tabular}

Note. This table presents estimates of Pooled OLS and fixed effect panel model of cross-border and domestic mergers and acquisition activity. The dependent variable is corruption perception index (CPI) for the year $t$ and country i. To control for endogeneity, some independent variables are lagged. Heteroskedasticity-corrected t-statistics are in parentheses. The variable definitions are provided in Appendix A. Country and time fixed effects are included. $* * *, * *$, and $*$ denote statistical significance at the $1 \%, 5 \%$, and $10 \%$ levels, respectively.

As it is presented in Table 6, all the measures of M\&A activity are statistically significant in both Pooled OLS and fixed effect panel analysis. The results confirms our previous results in table 3 .

\subsubsection{Regional Subsamples}

To test the robustness of the sample data, we divide the data into regional subsamples and test the hypotheses for each subsample. The regional subsamples are: North and South America, Europe, Africa and the Middle East, and Asia and Oceania. Since the subsamples are fairly small, we use the simple OLS regression to estimate the coefficients. Table 7 summarizes the results. Results of domestic M\&A activity are not shown in the interest of brevity.

Table 7. Robustness tests, regional subsamples

\begin{tabular}{|c|c|c|c|c|c|c|c|c|}
\hline & \multicolumn{4}{|c|}{ North and South America } & \multicolumn{4}{|l|}{ Europe } \\
\hline & CPI & $\mathrm{CPI}$ & CPI & $\mathrm{CPI}$ & CPI & CPI & CPI & CPI \\
\hline $\begin{array}{l}\text { Log Cross-border } \\
\text { value per year } \\
(\mathrm{t}-1)\end{array}$ & $\begin{array}{r}0.161 * * * \\
(3.34)\end{array}$ & & & & $\begin{array}{r}0.473 * * * * \\
(7.14)\end{array}$ & & & \\
\hline $\begin{array}{l}\text { Log Cross-border } \\
\text { number per } \\
\text { year }_{(\mathrm{t}-1)}\end{array}$ & & $\begin{array}{r}0.482^{* * * *} \\
(3.78)\end{array}$ & & & & $\begin{array}{c}1.13 * * * \\
(10.39)\end{array}$ & & \\
\hline $\begin{array}{l}\text { Log Total value } \\
\text { per year } \\
(\mathrm{t}-1)\end{array}$ & & & $\begin{array}{r}0.192 * * * * \\
(3.48)\end{array}$ & & & & $\begin{array}{r}0.48^{* * * *} \\
(6.57)\end{array}$ & \\
\hline $\begin{array}{l}\text { Log Total number } \\
\text { per year } \text { yt-1) }^{2}\end{array}$ & & & & $\begin{array}{r}0.604 * * * \\
(4.16)\end{array}$ & & & & $\begin{array}{r}1.105^{* * * *} \\
(9.47)\end{array}$ \\
\hline Former colony & $\begin{array}{r}0.253 \\
(1.07)\end{array}$ & $\begin{array}{l}0.266 \\
(1.03)\end{array}$ & $\begin{array}{l}0.321 \\
(1.38)\end{array}$ & $\begin{array}{r}0.458 \\
(1.91)\end{array}$ & $\begin{array}{r}-1.03 * * * \\
(-5.95)\end{array}$ & $\begin{array}{r}-1.335 * * * \\
(-8.42)\end{array}$ & $\begin{array}{r}-1.119 * * * \\
(-6.26)\end{array}$ & $\begin{array}{r}-1.285 * * * \\
(-8.27)\end{array}$ \\
\hline $\begin{array}{l}\text { Log GDP per } \\
\text { Capita }_{(t-1)}\end{array}$ & $\begin{array}{r}-0.499 * * * \\
(-3.33)\end{array}$ & $\begin{array}{r}-0.633 * * * \\
(-4.03)\end{array}$ & $\begin{array}{r}-0.562 * * * \\
(-3.58)\end{array}$ & $\begin{array}{r}-0.727 * * * * \\
(-4.22)\end{array}$ & $\begin{array}{l}0.109 \\
(0.66)\end{array}$ & $\begin{array}{l}-0.095 \\
(-0.61)\end{array}$ & $\begin{array}{l}0.141 \\
(0.82)\end{array}$ & $\begin{array}{l}-0.066 \\
(-0.38)\end{array}$ \\
\hline $\mathrm{EF}$ & $\begin{array}{r}-5.186^{* * * *} \\
(-8.49)\end{array}$ & $\begin{array}{r}-5.245^{* * *} * \\
(-9.22)\end{array}$ & $\begin{array}{r}-5.017 * * * \\
(-8.6)\end{array}$ & $\begin{array}{r}-5.031 * * * \\
(-9.12)\end{array}$ & $\begin{array}{c}0.747 \\
(1.08)\end{array}$ & $\begin{array}{r}-0.171 \\
(-0.28)\end{array}$ & $\begin{array}{l}0.858 \\
(1.24)\end{array}$ & $\begin{array}{l}-0.078 \\
(-0.13)\end{array}$ \\
\hline Oil Exporter & $\begin{array}{r}-1.811 * * * \\
(-6.37)\end{array}$ & $\begin{array}{r}-1.679 * * * \\
(-5.95)\end{array}$ & $\begin{array}{r}-1.779 * * * \\
(-6.11)\end{array}$ & $\begin{array}{r}-1.55^{* * * *} \\
(-5.45)\end{array}$ & $\begin{array}{r}-0.672 * * * \\
(-3.86)\end{array}$ & $\begin{array}{r}-0.632 * * * \\
(-3.92)\end{array}$ & $\begin{array}{r}-0.765^{* * * *} \\
(-4.48)\end{array}$ & $\begin{array}{r}-0.662 * * * * \\
(-3.71)\end{array}$ \\
\hline $\begin{array}{l}\text { Log Government } \\
\text { expenditure }\end{array}$ & $\begin{array}{l}0.035 \\
(0.26)\end{array}$ & $\begin{array}{l}-0.014 \\
(-0.11)\end{array}$ & $\begin{array}{l}-0.008 \\
(-0.05)\end{array}$ & $\begin{array}{r}-0.069 \\
(-0.5)\end{array}$ & $\begin{array}{r}0.652 * * * \\
(2.93)\end{array}$ & $\begin{array}{r}0.234 * * \\
(2.53)\end{array}$ & $\begin{array}{r}0.694 * * * \\
(2.8)\end{array}$ & $\begin{array}{r}0.328 * * \\
(2.31)\end{array}$ \\
\hline Log population & $\begin{array}{r}-0.918 * * * \\
(-9.25)\end{array}$ & $\begin{array}{r}-1.046 * * * \\
(-7.46)\end{array}$ & $\begin{array}{r}-0.968 * * * \\
(-9.31)\end{array}$ & $\begin{array}{r}-1.185 * * * \\
(-7.9)\end{array}$ & $\begin{array}{r}-0.857 * * * \\
(-9.52)\end{array}$ & $\begin{array}{r}-1.239 * * * \\
(-12.75)\end{array}$ & $\begin{array}{r}-0.89 * * * \\
(-9.37)\end{array}$ & $\begin{array}{r}-1.314 * * * \\
(-11.51)\end{array}$ \\
\hline Political rights & $\begin{array}{r}-0.16 \\
(-1.23)\end{array}$ & $\begin{array}{l}-0.087 \\
(-0.61)\end{array}$ & $\begin{array}{l}-0.183 \\
(-1.39)\end{array}$ & $\begin{array}{l}-0.104 \\
(-0.75)\end{array}$ & $\begin{array}{r}-1.826 * * * \\
(-5.75)\end{array}$ & $\begin{array}{r}-1.043 * * * \\
(-3.71)\end{array}$ & $\begin{array}{r}-2.286 * * * * \\
(-5.67)\end{array}$ & $\begin{array}{r}-1.66 * * * \\
(-5.11)\end{array}$ \\
\hline French legal origin & $\begin{array}{r}-5.393 * * * \\
(-12.76)\end{array}$ & $\begin{array}{r}-4.848 * * * * \\
(-10.42)\end{array}$ & $\begin{array}{r}-5.331 * * * \\
(-13.09)\end{array}$ & $\begin{array}{r}-4.456 * * * \\
(-9.07)\end{array}$ & $\begin{array}{r}-1.231 * * * \\
(-5.78)\end{array}$ & $\begin{array}{r}-0.587 * * * \\
(-3.39)\end{array}$ & $\begin{array}{r}-1.31 * * * * \\
(-5.87)\end{array}$ & $\begin{array}{r}-0.83 * * * * \\
(-4.5)\end{array}$ \\
\hline Primary religion & Omitted $^{1}$ & Omitted $^{1}$ & Omitted $^{1}$ & Omitted $^{1}$ & $\begin{array}{r}0.52 * * * \\
(3.27)\end{array}$ & $\begin{array}{r}0.466 * * * * \\
(3.4)\end{array}$ & $\begin{array}{r}0.484 * * * \\
(2.77)\end{array}$ & $\begin{array}{l}0.215 \\
(1.39)\end{array}$ \\
\hline Constant & $\begin{array}{r}29.822 * * * \\
(11.77)\end{array}$ & $\begin{array}{r}32.13^{* * * *} \\
(10.65)\end{array}$ & $\begin{array}{r}30.91^{* * * *} \\
(11.6)\end{array}$ & $\begin{array}{r}34.153^{* * * *} \\
(10.72)\end{array}$ & $\begin{array}{r}16.395^{* * * *} \\
(7.31)\end{array}$ & $\begin{array}{r}23.765 * * * \\
(10.46)\end{array}$ & $\begin{array}{r}16.711^{* * * *} \\
(7.26)\end{array}$ & $\begin{array}{r}24.658^{* * * *} \\
(9.22)\end{array}$ \\
\hline Observations & 172 & 175 & 172 & 175 & 256 & 256 & 256 & 256 \\
\hline $\mathrm{R}^{2}$ & 0.87 & 0.82 & 0.88 & 0.80 & 0.81 & 0.71 & 0.82 & 0.74 \\
\hline
\end{tabular}




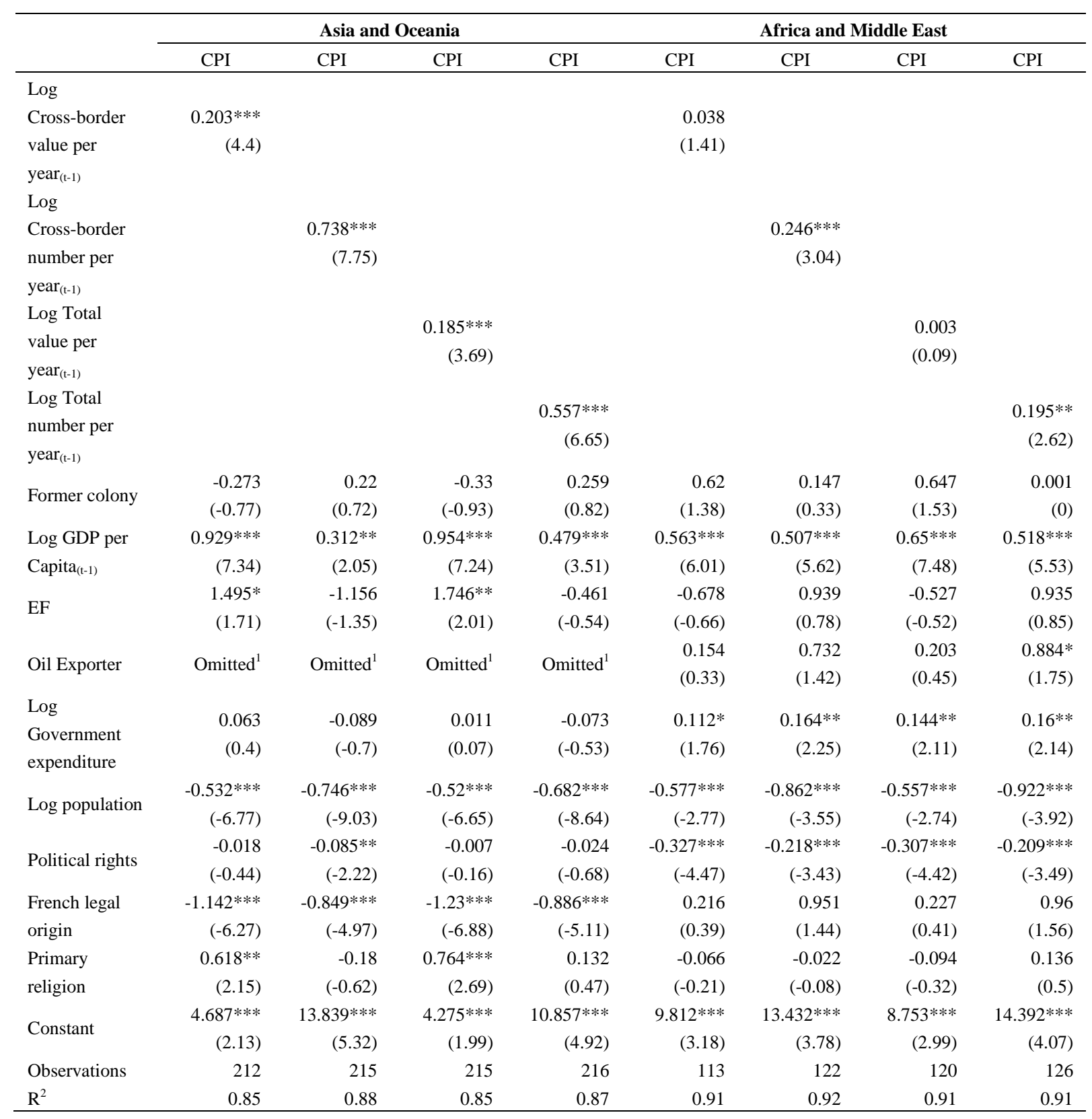

Note. This table presents estimates of OLS regression of cross-border and total M\&A activity. The dependent variable is corruption perception index (CPI) for the year $\mathrm{t}$ and country i. To control for endogeneity, some independent variables are lagged one year. Heteroskedasticity-corrected t-statistics are in parentheses. The variable definitions are provided in Appendix A. ***, **, and * denote statistical significance at the $1 \%, 5 \%$, and $10 \%$ levels, respectively.

${ }^{1}$ The variable is omitted because of collinearity.

Most of the subsamples have positive and statistically significant coefficients for all the measures of M\&A activity, which confirms the idea that M\&A activity can reduce the level of corruption in these subsamples. As for Africa and the Middle East, at least one of the two M\&A activity pairs (number or value) is statistically significant, which further confirms the results.

\subsubsection{Outliers}

To identify the outliers, we used a scatter plot to visually identify the possible outliers. Figure 2 and Figure 3 show the scatter plot for total number per year and total value per year vs. CPI index. A cursory look at these graphs suggests that the United States and the United Kingdom are indeed outliers. As a robustness check, we remove these two countries from the sample data and run regressions to determine the effect of M\&A activity on corruption. 


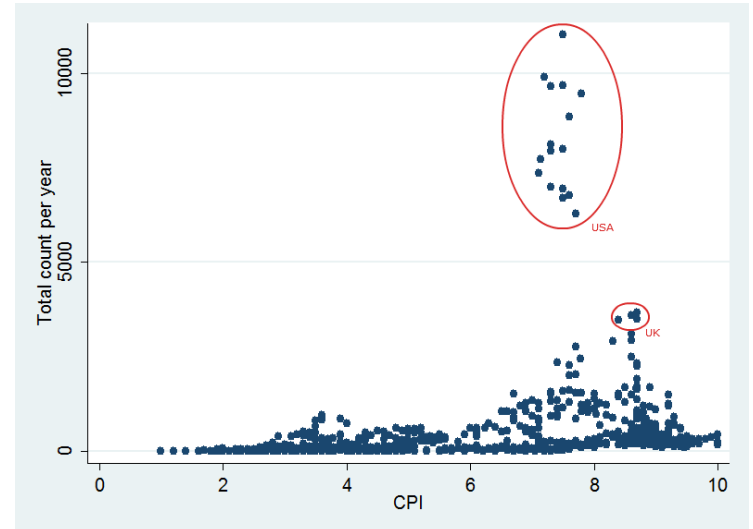

Figure 2. Scatter plot of total number per year and CPI

The horizontal line represents corruption perception index and the vertical line represents the total number per year. Circled observations are noteworthly.

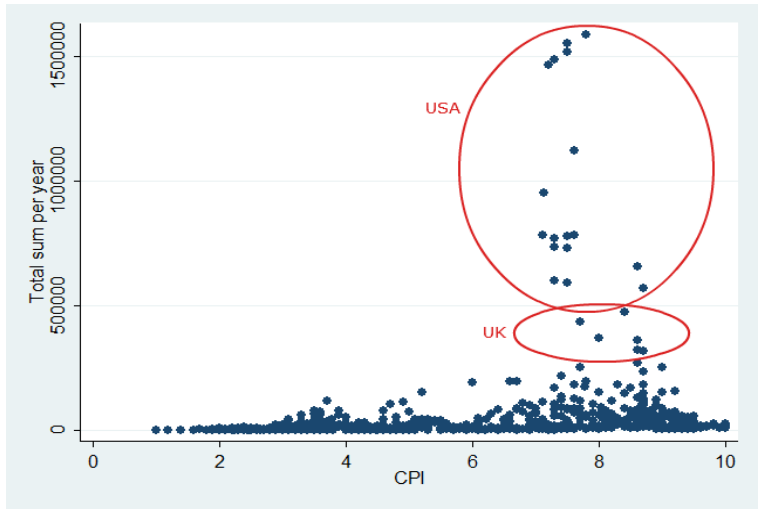

Figure 3. Scatter plot of total value per year and CPI

The horizontal line represents corruption perception index and the vertical line represents the total number per years. Circled observations are noteworthy.

Table 9. Robustness tests, removing outliers

\begin{tabular}{|c|c|c|c|c|}
\hline & $\mathrm{CPI}$ & $\mathrm{CPI}$ & $\mathrm{CPI}$ & $\mathrm{CPI}$ \\
\hline Log Cross-border value per year ${ }_{(t-1)}$ & $\begin{array}{r}0.054 * * * \\
(3.38)\end{array}$ & & & \\
\hline Log Cross-border & & $0.173 * * *$ & & \\
\hline Number per year $(t-1)$ & & $(3.67)$ & & \\
\hline Log Total value per year $(\mathrm{t}-1)$ & & & $\begin{array}{r}0.053 * * * \\
(2.62)\end{array}$ & \\
\hline Log Total number per year $(\mathrm{t}-1)$ & & & & $\begin{array}{r}0.192 * * * \\
(3.45)\end{array}$ \\
\hline Former colony & $\begin{array}{r}-0.813 * * \\
(-2.03)\end{array}$ & $\begin{array}{r}-0.738^{*} \\
(-1.93)\end{array}$ & $\begin{array}{r}-0.814 * * \\
(-2.03)\end{array}$ & $\begin{array}{r}-0.749 * * \\
(-1.97)\end{array}$ \\
\hline Log GDP per Capita ${ }_{(t-1)}$ & $\begin{array}{r}0.19^{* *} \\
(2.42)\end{array}$ & $\begin{array}{r}0.168 * * \\
(2.01)\end{array}$ & $\begin{array}{r}0.192 * * \\
(2.36)\end{array}$ & $\begin{array}{r}0.13 \\
(1.61)\end{array}$ \\
\hline $\mathrm{EF}$ & $\begin{array}{r}-2.09^{* *} \\
(-2.43)\end{array}$ & $\begin{array}{r}-1.955 * * \\
(-2.4)\end{array}$ & $\begin{array}{r}-2.021 * * \\
(-2.35)\end{array}$ & $\begin{array}{r}-1.958 * * \\
(-2.43)\end{array}$ \\
\hline Oil Exporter & $\begin{array}{r}-1.166^{* * * *} \\
(-2.99)\end{array}$ & $\begin{array}{r}-1.04 * * * \\
(-2.72)\end{array}$ & $\begin{array}{r}-1.139 * * * \\
(-2.88)\end{array}$ & $\begin{array}{r}-1.016^{* * * *} \\
(-2.63)\end{array}$ \\
\hline Log Government expenditure & $\begin{array}{l}0.056 \\
(0.97)\end{array}$ & $\begin{array}{l}0.073 \\
(1.21)\end{array}$ & $\begin{array}{r}0.06 \\
(1.01)\end{array}$ & $\begin{array}{c}0.065 \\
(1.06)\end{array}$ \\
\hline
\end{tabular}




\begin{tabular}{|c|c|c|c|c|}
\hline \multirow{2}{*}{ Log population } & $-0.737 * * *$ & $-0.763 * * *$ & $-0.752 * * *$ & $-0.803 * * *$ \\
\hline & $(-5.96)$ & $(-6.51)$ & $(-6.02)$ & $(-6.56)$ \\
\hline \multirow{2}{*}{ Political rights } & $-0.082 *$ & $-0.075^{*}$ & $-0.088 *$ & -0.075 \\
\hline & $(-1.67)$ & $(-1.67)$ & $(-1.84)$ & $(-1.63)$ \\
\hline \multirow{2}{*}{ French legal origin } & $-1.232 * * *$ & $-1.19 * * *$ & $-1.233^{* * *}$ & $-1.163 * * *$ \\
\hline & $(-2.78)$ & $(-2.91)$ & $(-2.79)$ & $(-2.83)$ \\
\hline \multirow{2}{*}{ Primary religion } & 0.593 & 0.536 & 0.572 & 0.53 \\
\hline & $(1.12)$ & $(1.1)$ & (1.09) & (1.1) \\
\hline \multirow{2}{*}{ Constant } & $17.659^{* * *}$ & $17.886^{* * * *}$ & $17.866^{* * * *}$ & $18.721 * * *$ \\
\hline & (7.66) & (7.82) & (7.61) & (8.05) \\
\hline Observations & 721 & 736 & 731 & 741 \\
\hline $\mathrm{R}^{2}$ & 0.75 & 0.78 & 0.75 & 0.78 \\
\hline
\end{tabular}

Note. This table presents estimates of random effect model of cross-border and total M\&A activity. The dependent variable is corruption perception index (CPI) for the year $\mathrm{t}$ and country i. To control for endogeneity, some independent variables are lagged one year. Heteroskedasticity-corrected t-statistics are in parentheses. The variable definitions are provided in Appendix A. ***, **, and * denote statistical significance at the $1 \%, 5 \%$, and $10 \%$ levels, respectively.

Table 9 sums up the results of random effect model panel regression. The results of this table match the previous results and support the hypothesis. All the M\&A activity measures all statistically significant and have the expected sign. In fact, these outlier countries do not affect the results.

\section{Conclusion}

This paper makes a systematic attempt to estimate the effects of openness to trades through mergers and acquisitions on corruption. We use two different measures of corruption (CPI and ICRG) and two different measures of M\&A activity (number and dollar amount per year) on a sample of 50 countries during the 1998-2013 period. Our results indicate that M\&A activity is a robust determinant of corruption. More M\&A activity results in lower national levels of corruption in a host country. This result is robust due to result confirmation in a series of robustness checks. The literature has previously suggested that higher corruption levels deter foreign direct investment and mergers and acquisitions. Here we find that the opposite causality also holds; higher merger and acquisition activity is shown to deter corruption.

\section{References}

Acemoglu, D., Johnson, S., \& Robinson, J. A. (2001). The Colonial Origins of Comparative Development: An Empirical Investigation. American Economic Review, 91(5), 1369-1401. https://doi.org/10.1257/aer.91.5.1369

Acemoglu, D., Johnson, S., \& Robinson, J. A. (2002). Reversal of Fortune: Geography and Institutions in the Making of the Modern World Income Distribution. The Quarterly Journal of Economics, 117(4), 1231-1294. https://doi.org/10.1162/003355302320935025

Ades, A. \& Di Tella, R. (1995). Competition and Corruption. Working Paper, Keble College, Oxford University.

Ades, A., \& Di Tella, R. (1997). The New Economics of Corruption: A Survey and some New Results. Political Studies, 45(3), 496-515. https://doi.org/10.1111/1467-9248.00093

Ades, A., \& Di Tella, R. (1999). Rents, Competition, and Corruption. American Economic Review, 89(4), 982-993. https://doi.org/10.1257/aer.89.4.982

Alonso, J. A. (2007). Inequality, institutions and progress: A debate between history and the present. CEPAL Review, (93), 61-80. https://doi.org/10.18356/7edf20f2-en

Bardhan, P. (1997). Corruption and Development: A Review of the Issues. Journal of Economic Literature, 35(3), 1320-1346.

Barro, R. J., \& Lee, J. W. (1994). Sources of economic growth. Carnegie-Rochester Conference Series on Public Policy, 40, 1-46. https://doi.org/10.1016/0167-2231(94)90002-7

Beck, T., Demirgüç-Kunt, A., \& Levine, R. (2003). Law, endowments, and finance. Journal of Financial Economics, 70(2), 137-181. https://doi.org/10.1016/S0304-405X(03)00144-2

BRAGUINSKY, S. (1996). Corruption and Schumpeterian Growth in Different Economic Environments. Contemporary Economic Policy, 14(3), 14-25. https://doi.org/10.1111/j.1465-7287.1996.tb00620.x 
Bris, A., \& Cabolis, C. (2008). The Value of Investor Protection: Firm Evidence from Cross-Border Mergers. Review of Financial Studies, 21(2), 605-648. https://doi.org/10.1093/rfs/hhm089

Chen, V. Z., Li, J., \& Shapiro, D. M. (2012). International reverse spillover effects on parent firms: Evidences from emerging-market MNEs in developed markets. European Management Journal, 30(3), 204-218. https://doi.org/10.1016/j.emj.2012.03.005

Erel, I., Liao, R. C., \& Weisbach, M. S. (2012). Determinants of Cross-Border Mergers and Acquisitions. The Journal of Finance, 67(3), 1045-1082. https://doi.org/10.1111/j.1540-6261.2012.01741.x

Gerring, J., \& Thacker, S. C. (2005). Do Neoliberal Policies Deter Political Corruption? International Organization, 59(01), 233-254. https://doi.org/10.1017/S0020818305050083

Goldsmith, A. A. (1999). Slapping the Grasping Hand. American Journal of Economics and Sociology, 58(4), 865-883. https://doi.org/10.1111/j.1536-7150.1999.tb03398.x

Gorg, H. (2004). Much Ado about Nothing? Do Domestic Firms Really Benefit from Foreign Direct Investment? The World Bank Research Observer, 19(2), 171-197. https://doi.org/10.1093/wbro/lkh019

Habib, M., \& Zurawicki, L. (2001). Country-level investments and the effect of corruption - some empirical evidence. International Business Review, 10(6), 687-700. https://doi.org/10.1016/S0969-5931(01)00038-5

Habib, M., \& Zurawicki, L. (2002). Corruption and Foreign Direct Investment. Journal of International Business Studies, 33(2), 291-307. https://doi.org/10.1057/palgrave.jibs.8491017

Haskel, J. E., Pereira, S. C., \& Slaughter, M. J. (2007). Does Inward Foreign Direct Investment Boost the Productivity of Domestic Firms? Review of Economics and Statistics, 89(3), 482-496. https://doi.org/10.1162/rest.89.3.482

Henisz, W. (2000). The institutional environment for multinational investment. Journal of Law, Economics, and Organization, 16(2), 334-364. https://doi.org/10.1093/jleo/16.2.334

Jain, A. K. (2001). Corruption: A Review. Journal of Economic Surveys, 15(1), 71-121. https://doi.org/10.1111/1467-6419.00133

Javorcik, B. S. (2004). Does Foreign Direct Investment Increase the Productivity of Domestic Firms? In Search of Spillovers Through Backward Linkages. American Economic Review, 94(3), 605-627. https://doi.org/10.1257/0002828041464605

Javorcik, B. S., \& Wei, S.-J. (2009). Corruption and cross-border investment in emerging markets: Firm-level evidence. Journal of International Money and Finance, 28(4), 605-624. https://doi.org/10.1016/j.jimonfin.2009.01.003

Kaufmann, D. (2004). Corruption, Governance and Security: Challenges for the Rich Countries and the World. SSRN Electronic Journal. https://doi.org/10.2139/ssrn.605801

Knack, S., \& Azfar, O. (2003). Trade intensity, country size and corruption. Economics of Governance, 4(1), 1-18. https://doi.org/10.1007/s101010200051

La Porta, R., Lopez De Silanes, F., Shleifer, A., \& Vishny, R. (1999). The Quality of Government. The Journal of Law, Economics and Organization, (15), 222-279. https://doi.org/10.1093/jleo/15.1.222

Lambsdorff, J. G. (1999). Corruption in empirical research: A review. Transparency International, processed, 6.

Lambsdorff, J. G. (2003). How Corruption Affects Productivity. Kyklos, 56(4), 457-474. https://doi.org/10.1046/j.0023-5962.2003.00233.x

Lambsdorff, J. G. (2005). Consequences and Causes of Corruption: What Do We Know From a Cross-Section of Countries? University of Passau, Passau.

Lambsdorff, J. G., \& Cornelius, P. (2000). Corruption, foreign investment and growth. The Africa Competitiveness Report, 2001, 70-78.

Landes, D. (1998). The Wealth and Poverty of Nations. New York, N.Y.: W.W. Norton.

Larraín B., F., \& Tavares, J. (2004). Does Foreign Direct Investment Decrease Corruption? Cuadernos de Economía, 41(123). 217-230. https://doi.org/10.4067/S0717-68212004012300003

Lederman, D., Loayza, N. V., \& Soares, R. R. (2005). Accountability And Corruption: Political Institutions Matter. Economics and Politics, 17(1), 1-35. https://doi.org/10.1111/j.1468-0343.2005.00145.x

Leite, C., \& Weidmann, J. (1999). Does Mother Nature Corrupt: Natural Resources, Corruption, and Economic 
Growth. IMF Working Papers, 99(85), 1. https://doi.org/10.5089/9781451850734.001

Levine, R. (2005). Law, Endowments and Property Rights. Journal of Economic Perspectives, 19(3), 61-88. https://doi.org/10.1257/089533005774357842

Martynova, M., \& Renneboog, L. (2008). Spillover of corporate governance standards in cross-border mergers

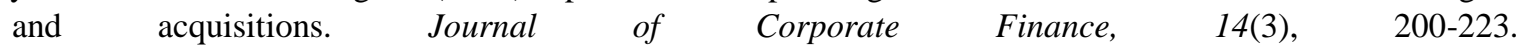
https://doi.org/10.1016/j.jcorpfin.2008.03.004

Mauro, P. (1995). Corruption and Growth. The Quarterly Journal of Economics, 110(3), 681-712. https://doi.org/10.2307/2946696

Mauro, P. (1997). The Effects of Corruption on Growth, Investment, and Government Expenditure: A Cross-Country Analysis. In K. A. Elliot (Ed.), Corruption and the Global Economy (pp. 83-107). Institute For International Economics.

Paldam, M. (2002). The cross-country pattern of corruption: Economics, culture and the seesaw dynamics. European Journal of Political Economy, 18(2), 215-240. https://doi.org/10.1016/S0176-2680(02)00078-2

Pinto, P. M., \& Zhu, B. (2016). Fortune or Evil? The Effect of Inward Foreign Direct Investment on Corruption. International Studies Quarterly, 60(4), 693-705. https://doi.org/10.1093/isq/sqw025

Rose-Ackerman, S. (1975). The economics of corruption. Journal of Public Economics, 4(2), 187-203. https://doi.org/10.1016/0047-2727(75)90017-1

Rose-Ackerman, S. (1997). The Political Economy of Corruption. Corruption and the Global Economy, 31-60.

Rose-Ackerman, S. (1999). Corruption and Government, Causes, Consequences and Reform. Cambridge, UK: Cambridge University Press. https://doi.org/10.1017/CBO9781139175098

Sachs, J., \& Warner, A. (1995). Natural Resource Abundance and Economic Growth. https://doi.org/10.3386/w5398

Sandholtz, W., \& Gray, M. M. (2003). International Integration and National Corruption. International Organization, 57(4), 761-800. https://doi.org/10.1017/S0020818303574045

Sandholtz, W., \& Koetzle, W. (2000). Accounting for Corruption: Economic Structure, Democracy, and Trade. International Studies Quarterly, 44(1), 31-50. https://doi.org/10.1111/0020-8833.00147

Scott, J. C. (1972). Comparative Political Corruption. Englewood Cliffs, Nj: Prentice-Hall.

Shleifer, A., \& Vishny, R. W. (1993). Corruption. The Quarterly Journal of Economics, 108(3), 599-617. https://doi.org/10.2307/2118402

Stulz, R. M., \& Williamson, R. (2003). Culture, openness, and finance. Journal of Financial Economics, 70(3), 313-349. https://doi.org/10.1016/S0304-405X(03)00173-9

Sung, H. E., \& Chu, D. (2003). Does Participation in the Global Economy Reduce Political Corruption? An Empirical Inquiry. International Journal of Comparative Criminology, 3(2), 94-118.

Tanzi, V. (1998). Corruption Around the World: Causes, Consequences, Scope, and Cures. Staff Papers International Monetary Fund, 45(4), 559-554. https://doi.org/10.2307/3867585

Treisman, D. (2000). The causes of corruption: a cross-national study. Journal of Public Economics, 76(3), 399-457. https://doi.org/10.1016/S0047-2727(99)00092-4

Treisman, D. (2007). What Have We Learned About the Causes of Corruption from Ten Years of Cross-National Empirical Research? Annual Review of Political Science, 10(1), 211-244. https://doi.org/10.1146/annurev.polisci.10.081205.095418

Ullekh, N. P. (2012). Ak Antony: Post Defence Controversies, Mr Clean Is Mr Cool. Retrieved from http://Articles.Economictimes.Indiatimes.Com/2012-04-15/News/31342440_1_Defence-Deals-Adarsh-Mod ernisation-Drive

UNCTAD. (2000). Foreign Direct Investment Database. Retrieved from http://Stats.Unctad.Org/Fdi/

Wei, S. J. (2000). How Taxing is Corruption on International Investors? Review of Economics and Statistics, 82(1), 1-11. https://doi.org/10.1162/003465300558533

Wei, S. J. (2000). Natural Openness and Good Government. https://doi.org/10.3386/w7765 


\section{Appendix A}

Definition and expected signs of the variables

\begin{tabular}{ll}
\hline Variable Name Definition and Source & $\begin{array}{c}\text { Expected } \\
\text { Sign }\end{array}$ \\
\hline Corruption indexes: &
\end{tabular}

Corruption indexes:

Corruption Corruption Perception Index (CPI) is the index produced annually by Transparency International. This index Perception has become a widely-used measure of corruption in the literature. It is an aggregated, standardized "poll of Index polls" of experts, international business people, and citizens of each country covered. Every score thus captures the perceptions of both foreigners and nationals of the country being assessed. Transparency International uses a similar definition of corruption as us: "the misuse of public power for private benefit." The index assigns a score, ranging from 0 (most corrupt) to 10 (least corrupt), to each country in each year. From 2013 Transparency International decided to present the index ranging from 0 to 100. For simplicity the index is divided by 10 for 2012 and 2013. Source: Transparency International, various years.

International International Country Risk Guide (ICRG) corruption index is an index produced by Political Risk Services. Country This index is a survey-based indicator, which has been widely used in the economics literature. This index is Risk $\quad$ produced monthly. We use the mean of the months of each year as the index for that year. The index scales Guide from 0 to 6. Low scores on the ICRG corruption index indicate that "high government officials are likely to demand special payments". Source: Political Risk Services, various years.

Merger and Acquisition activity:

Cross-border As a measure of M\&A activity, we calculate the natural logarithm of the number of all cross-national deals number which happened in a year for each country, whether the country was target or acquirer. We include only deals per year for which the acquirer owns less than $50 \%$ of the shares prior to transaction and owns at least $50 \%$ of the shares after the transaction. Deals with no information about before or after percentage of shares owned are excluded. The data is collected from Thomson Reuters's SDC Platinum database spanning from 1998 to 2013.

Cross-border value We have another measure of M\&A activity which is the natural logarithm of the sum of all cross-national per year deals' transaction value in US dollars, whether the country was target or acquirer. The deals with no information on deal value, or deals which did not make the acquirer the owner of $50 \%$ of the share were excluded. Our data is taken from Thomson Reuters's SDC Platinum database for the years 1998 to 2013.

Domestic number This variable is the natural logarithm of the total number of domestic M\&A deals per years in a country. We per year excluded the deals which did not make the acquirer a controlling shareholder (more than $50 \%$ of the shares) or the deals which the acquirer was already a controlling shareholder. The data is downloaded from Thomson Reuters's SDC Platinum database.

Domestic value This variable is the natural logarithm of the total domestic transaction value in US dollars. The deals which per year do not pass the ownership of $50 \%$ of the shares are excluded. This variable is downloaded from Thomson Reuters's SDC Platinum database.

Total number We construct this variable as the natural logarithm of the total number of domestic and international deals in per year a country. This variable is simply a natural logarithm of the sum of Cross-border count per year and Domestic count per year.

Total value This variable is the natural logarithm of the total value of the cross-national and domestic deals in a country per year per year. The variable is the sum of Cross-border sum per year and Domestic sum per year.

Control Variables:

Former colony is a dummy variable that takes the value of one if the country was a former colony after 1825 and zero otherwise. Source: Barro and Lee (1994).

Per capita GDP is the natural logarithm of the per capita GDP in US dollars. Source: World Bank and Taiwan National Statistics.

Ethnolinguistic Ethnolinguistic Fractionalization (ER) measures ethnolinguistic fractionalization which is the probability Fractionalization that two randomly selected individuals within a country belong to the same religious and ethnic group scaling from 0 to 1. Source: La Porta et al. (1999).

Oil exporter is a dummy variable for oil exporting countries. The dummy takes the value of 1 if the country's fuel export is more than $30 \%$ of the total merchandise exports. Source: World Bank.

Government is the natural logarithm of the government final consumption expenditure as a share of GDP. Source: World expenditure Bank and Taiwan National Statistics.

Population $\quad$ is the natural logarithm of the total population of a country. Source: World Bank and Taiwan National Statistics. 
Political rights

is the degree to which people are free to participate in the political process, freedom to vote for distinct alternatives in legitimate elections, freedom to compete for public office, join political parties and organizations, and elect representatives who have a decisive impact on public policies and are accountable to the electorate. This index is scaled from 0 to 7 which 1 denotes a high political freedom. Source: Freedom House.

French legal origin is a dummy variable denoting if the legal origin of the country is civil French law. Source: La Porta et al. (1999).

Primary religion is a dummy variable which takes the value 1 if the primary religion of the country is Protestant. Source: La Porta et al. (1999).

\section{Copyrights}

Copyright for this article is retained by the author(s), with first publication rights granted to the journal.

This is an open-access article distributed under the terms and conditions of the Creative Commons Attribution license (http://creativecommons.org/licenses/by/4.0/). 